\title{
Relevansi Nilai Selisih Loans Book Value dan Loans Fair Value, Book Value Per Share, Earnings Per Share dan Ukuran Perusahaan
}

\author{
Dina Bakti Pertiwi ${ }^{1}$, Novrys Suhardianto ${ }^{*}$ \\ 1) Fakultas Ekonomi dan Bisnis Universitas Airlangga \\ Jl. Airlangga 4, Surabaya 60286 \\ * Penulis korespondensi; email: novrys@feb.unair.ac.id
}

\begin{abstract}
ABSTRAK
Salah satu dampak konvergensi IFRS adalah kecenderungan meninggalkan historical cost menuju fair value terutama untuk instrumen keuangan, salah satunya adalah pinjaman yang diberikan bank. Oleh sebab itu, manfaat penggunaan historical cost maupun fair value perlu dievaluasi. Penelitian ini bertujuan untuk mengetahui hubungan selisih loans book value dan loans fair value, book value per share, earnings per share dan ukuran perusahaan dari bank pengguna standar akuntansi keuangan yang konvergen dengan IFRS terhadap harga saham perbankan. Sampel yang digunakan adalah bank yang terdaftar di Bursa Efek Indonesia selama periode 2010-2013. Hubungan selisih loans book value dan loans fair value, book value per share, earnings per share dan ukuran perusahaan terhadap harga saham perbankan dianalisis menggunakan regresi linier berganda. Hasil penelitian ini menunjukkan bahwa selisih loans book value dan loans fair value, book value per share, earnings per share dan ukuran perusahaan bisa digunakan untuk memrediksi harga saham perbankan. Dengan demikian, selisih nilai buku dan nilai wajar instrumen keuangan masih memiliki nilai relevan.
\end{abstract}

Kata kunci: IFRS; instrumen keuangan; selisih loans book value dan loans fair value.

\begin{abstract}
One of the impacts of IFRS convergence is the tendency to leave historical cost to the fair value primarily for financial instruments, one of which is bank loans. Therefore, the benefit of the use of historical cost and fair value needs to be examined. This study aims to evaluate the relationship of the difference between loan book value and fair value, book value per share, earnings per share and the company size to the stock price of banks that use accounting standard that has been converged to IFRS. The samples used are banks listed in Indonesia Stock Exchange during the period of 2010-2013. The relationship between the difference loans book value and fair value, book value per share, earnings per share and the size with the stock price were analyzed using multiple linear regression. The results of this study indicate that the difference between loans book value and fair value, book value per share, earnings per share and the size can be used to predict the stock price of bank. Thus, the difference between loan book value and fair value of financial instruments have a relevant value.
\end{abstract}

Keywords: IFRS; financial instrument; difference between loans book value and loans fair value.

\section{PENDAHULUAN}

Indonesia sebagai anggota G20 berkomitmen mengonvergensi standar akuntansi keuangan Indonesia (SAK) agar selaras dengan International Financial Reporting Standard (IFRS) yang disusun oleh International Accounting Standards Board (IASB). Sejak Ikatan Akuntan Indonesia (IAI) berkomitmen menerima IFRS pada 2008, proses konvergensi PSAK terhadap IFRS terus berlangsung sampai kesenjangan antara PSAK dan IFRS semakin mengecil dengan harapan relevansi laporan keuangan menjadi lebih baik. Salah satu dampak konvergensi PSAK terhadap IFRS adalah kecenderungan meninggalkan historical cost menuju fair value meskipun perdebatan soal kedua metode penilaian tersebut belum berakhir (Drago, et al. 2013). Penggunaan historical cost dipandang akan mengurangi relevansi laporan keuangan dalam pengambilan keputusan 
(Sonbay, 2010). Di sisi lain, penggunaan fair value bisa jadi meningkatkan relevansi namun berpotensi tidak andal, ketika tidak ada harga pasar yang dapat mengevaluasi aset dan liabilitas keuangan (Nissim, 2003). Selain itu, penggunaan fair value dapat mewakili intervensi pemerintah yang lebih tepat, melalui pengaturan pasar dan harga, untuk lembaga-lembaga yang bermasalah (Morris dan Sellon 1991).

Penggunaan fair value sangat disarankan oleh pernyataan standar akuntansi keuangan nomor 55 (PSAK 55) untuk instrumen keuangan. Salah satu instrumen keuangan paling dominan di perbankkan adalan loan atau pinjaman. Namun demikian, PSAK 60 memberikan panduan pengukuran nilai wajar untuk instrumen keuangan yang tidak dikuotasi di pasar aktif, misalnya pinjaman bank. Oleh sebab itu, bank seharusnya mampu mengukur nilai wajar pinjaman yang diberikan (loan).

Kewajiban menggunakan atau paling tidak mengungkapkan nilai wajar untuk instrumen keuangan sangat memengaruhi perbankan karena instrumen keuangan adalah komponen utama aset dan liabilitas bank. Sebagai lembaga intermediari, penyaluran kredit merupakan kegiatan yang mendominasi usaha perbankan. Dendawijaya (2005:49) mengemukakan bahwa dana yang dihimpun dari masyarakat dapat mencapai 80\%-90\% dari seluruh dana yang dikelola bank dan kegiatan perkreditan mencapai 70\%-80\% dari kegiatan usaha bank. Berdasarkan PSAK 55, kredit (loans) diukur pada biaya perolehan diamortisasi dan bank wajib mengungkapkan nilai wajarnya dalam catatan atas laporan keuangan. Pengungkapan loans fair value ini diharapkan dapat menambah relevansi saldo loan.

Informasi akuntasi dikatakan relevan apabila mampu mempengaruhi harga pasar saham (Reinita dan Deumes 2011). Untuk membuktikan bahwa pengungkapan fair value pinjaman bank (loan) bermanfaat bagi investor, penelitian ini bertujuan membuktikan bahwa perbedaan nilai buku dan nilai wajar loan memiliki kemampuan untuk memrediksi harga saham perbankan. Pengungkapan informasi fair value instrumen keuangan mempunyai relevansi nilai dalam menjelaskan harga saham (Hassan dan Norman, 2010). Pergerakan harga saham merupakan dampak dari keputusan investasi investor.

\section{Pengungkapan Nilai Wajar dan Harga Saham}

Menurut Francis dan Schipper (1999) hubungan antara informasi akuntansi dengan nilai pasar baik return saham maupun harga saham merupakan konsep value relevance. Infor- masi dapat dikatakan mempunyai relevansi nilai apabila dapat mempengaruhi harga pasar (Reinita, 2011). Dalam perkembangannya, penelitian-penelitian mengenai relevansi nilai memang diarahkan untuk menginvestigasi hubungan empiris antara nilai pasar modal (stock market values) dengan berbagai angka akuntasi, yang dimaksudkan untuk menilai kegunaan angka-angka akuntansi itu dalam penilaian ekuitas.

Terdapat beberapa penelitian yang menguji value relevance pengungkapan fair value dalam memrediksi nilai saham, diantaranya Khurana dan Kim (2003), Hassan dan Norman (2010), Agostino, et al. (2012) dan Drago, et al. (2013). Selain fair value dari instrumen keuangan, beberapa variabel lain yang diteliti dalam menjelaskan harga saham adalah book value per share, earnings per share, dan ukuran perusahaan.

Penelitian-penelitian tersebut menunjukkan hasil yang berbeda. Penelitian yang dilakukan oleh Khurana dan Kim (2003) menyimpulkan bahwa pengukuran historical cost untuk instrumen loans dan deposit lebih relevan dibandingkan dengan fair value-nya dalam menjelaskan harga saham, sedangkan fair value untuk instrumen keuangan jenis available-for-sale securities memiliki value relevance yang lebih baik dibandingkan dengan historical cost-nya dalam menjelaskan harga saham. Ini berarti bahwa fair value lebih relevan untuk instrumen keuangan tersebut tersedia di pasar. Berbeda dengan penelitian yang dilakukan oleh Khurana dan Kim (2003), Drago, et al. (2013) menunjukkan bahwa variabel selisih loans book value dan loans fair value berpengaruh terhadap harga saham. Hal ini mengindikasikan bahwa fair value mempunyai value relevance. Hassan dan Norman (2010) menemukan bahwa earnings per share, book value per share bisa digunakan untuk memrediksi harga saham, sedangkan fair value per share instrumen keuangan tidak berpengaruh terhadap harga saham. Senada dengan Hassan dan Norman (2010), Agostino, et al. (2012) menunjukkan bahwa earnings per share dapat menjelaskan variasi harga saham.

Hasil penelitian di atas menunjukkan bahwa pengungkapan nilai wajar tidak secara konsisten mampu memprediksi nilai saham. Value relevance pengungkapan nilai wajar dalam laporan keuangan perusahaan jasa keuangan perlu diselidiki lebih lanjut. Perusahaan jasa keuangan (bank) memiliki kewajiban untuk mengungkapan nilai wajar aset keuangannya (loan) sebagaimana diatur dalam PSAK 55. Di sisi lain, nilai loan mendominasi nilai aset yang dimiliki oleh bank. Pengguna laporan keuangan bank tertarik mengetahui kualitas dan nilai loan sebagai dasar pengambilan keputusan ketika nilai loan sangat signifikan. Di samping itu, 
kualitas loan yang tergambar dalam nilai wajar loan juga menarik minat pengguna laporan keuangan karena mampu merepresentasikan kemampuan bank dalam mengelola pinjaman yang diberikan.

Nilai wajar loan tidak cukup bermakna jika tidak dibandingkan dengan nilai perolehannya. Selisih antara loans book value dengan loans fair value mampu mendeteksi kemampu manajemen bank dalam menjaga kualitas loan. Kualitas loan yang baik tentu akan direspon secara positif oleh pengguna laporan keuangan. Dengan demikian, penelitian ini bertujuan untuk mengetahui apakah selisih loans book value dan loans fair value dapat digunakan untuk memprediksi nilai saham, sebagai proksi respon pengguna laporan keuangan.

Menurut Reinita (2011) "The value relevance of the financial statements could therefore be measured by the response in the market price or volume when accounting numbers are published, or by their ability to explain variations in the market price or volume". Jadi penelitian relevansi nilai adalah penelitian yang menguji hubungan informasi akuntansi dengan nilai pasar baik return saham maupun harga saham.

Menurut Francis dan Schipper (1999) terdapat empat kemungkinan interpretasi konsep value relevance:

1. Interpretasi pertama menyatakan bahwa informasi laporan keuangan menunjukkan harga saham dengan menangkap nilai intrinsik saham terhadap pergerakan harga saham. Relevansi nilai diukur sebagai laba yang dihasilkan dari implementasi accounting based trading rules. Interpretasi ini menggunakan asumsi bahwa harga tidak merefleksikan nilai intrinsik, tetapi angka-angka akuntansi yang merefleksikan nilai intrinsik. Kemudian pengujian yang dilakukan dengan asumsi ini memerlukan berbagai penyesuaian terhadap pergeseran risiko dari waktu ke waktu. Beberapa peneliti telah gagal menyesuaikan secara tepat dengan risiko-risiko dalam menerapkan trading rules.

2. Interpretasi ke dua menyatakan bahwa informasi keuangan merupakan suatu nilai yang relevan apabila mengandung variabel-variabel yang digunakan dalam model penilaian (valuation model) atau membantu dalam memprediksi variabel-variabel tersebut.

3. Interpretasi ke tiga menyatakan bahwa relevansi nilai dilihat dari adanya hubungan statistik yang mengukur apakah investor benarbenar menggunakan informasi keuangan dalam penetapan harga, sehingga relevansi nilai diukur dengan kemampuan informasi laporan keuangan untuk mengubah harga saham karena menyebabkan investor memperbaiki ekspektasinya.

4. Interpretasi ke empat menyatakan bahwa relevansi nilai diukur dengan kemampuan informasi laporan keuangan dalam menangkap atau mengikhtisarkan informasi, tanpa memandang sumbernya, yang mempengaruhi nilai saham. Interpretasi ini tidak menuntut bahwa laporan keuangan harus menjadi sumber informasi paling awal.

Interpretasi ke tiga dan ke empat dari relevansi nilai diindikasikan dengan hubungan statistik antara data akuntansi atau informasi keuangan dengan nilai pasar modal (capital market value) yang dapat berupa harga saham atau return saham. Penelitian ini menggunakan interpretasi relevansi nilai yang dikaitkan dengan hubungan statistik antara harga saham dengan selisih loans book value dan loans fair value, book value per share, earnings per share dan ukuran perusahaan pada interpretasi yang ketiga. Selisih loans book value dan loans fair value, book value per share, earnings per share, dan ukuran perusahaan mewakili informasi laporan keuangan dan capital market value yang digunakan adalah harga saham.

Beberapa hasil penelitian yang menjadi dasar rumusan hipotesis pada penelitian ini yaitu, Drago, et al. (2013) menemukan hasil bahwa variabel selisih loans book value dan loans fair value berpengaruh signifikan terhadap harga saham. Hal ini didukung oleh penelitian yang dilakukan oleh Hassan dan Norman (2010) bahwa informasi fair value mempunyai value relevance dalam menjelaskan harga saham. Hassan dan Norman (2010) menemukan bahwa variabel book value per share berpengaruh signifikan terhadap harga saham. Hal ini serupa dengan hasil penelitian yang dilakukan oleh Drago, et al. (2013) yang menemukan bahwa book value per share berpengaruh signifikan terhadap harga saham. Drago, et al. (2013) menemukan bahwa earnings per share berpengaruh signifikan terhadap harga saham. Hasil ini juga didukung oleh penelitian yang dilakukan Hassan dan Norman (2010) dan Agostino, et al. (2012) yang menemukan bahwa earnings per share berpengaruh terhadap saham. Djadmiko (2008) menemukan bahwa ada hubungan antara ukuran perusahaan dengan kinerja saham. hal ini menunjukkan bahwa perusahaan yang berukuran besar cenderung dapat menghasilkan laba yang lebih relatif tinggi karena mudah melakukan akses ke pasar untuk mendapatkan modal dibandingkan dengan perusahaan yang berukuran kecil. Sehingga dapat disimpulkan bahwa, ketika perusahaan besar dapat meng- 
hasilkan laba yang tinggi, investor akan tertarik untuk membeli saham perusahaan yang berukuran besar dibandingkan dengan perusahaan yang lebih kecil, dan pada akhirnya harga saham akan naik. Dari beberapa hasil penelitian tersebut, maka diajukan hipotesis sebagai berikut:

H1: Selisih loans book value dan loans fair value berpengaruh terhadap harga saham.

$\mathrm{H} 2$ : Book value per share berpengaruh terhadap harga saham.

H3: Earnings per share berpengaruh terhadap harga saham.

H4: Ukuran perusahaan berpengaruh terhadap harga saham.

\section{METODE PENELITIAN}

\section{Jenis Penelitian, Populasi dan Sampel}

Jenis penelitian termasuk penelitian kuantitatif dengan periode pengamatan dari tahun 2010 sampai tahun 2013. Sumber data yang digunakan dalam penelitian ini adalah data sekunder yang berasal dari website resmi Bursa Efek Indonesia (www.idx.co.id), Bank Indonesia (www.bi.go.id), dan Yahoo Finance (www.finance.yahoo.com). Variabel independen dalam penelitian ini, antara lain : selisih loans book value dan loans fair value, book value per share, earnings per share dan ukuran perusahaan. Variabel dependen adalah harga saham. Pengukuran masing-masing variabel tersebut disajikan pada Tabel 1.

Tabel 1. Identifikasi Variabel

\begin{tabular}{|c|c|c|}
\hline \multicolumn{3}{|c|}{ Jenis Variabel Nama Variabel } \\
\hline Variabel & Selisih Loans & Jumlah loans book value- \\
\hline Independen & $\begin{array}{l}\text { Book Value dan } \\
\text { Loans Fair } \\
\text { Value }\end{array}$ & jumlah loans fair value \\
\hline Variabel & Book Value Per & Jumlah Ekuitas $\div$ \\
\hline Independen & Share & Jumlah Saham Beredar \\
\hline Variabel & Earnings Per & Jumlah Laba Bersih $\div$ \\
\hline Independen & Share & Jumlah Saham Beredar \\
\hline Variabel & Ukuran & Log (Total Aset) \\
\hline Independen & Perusahaan & \\
\hline $\begin{array}{l}\text { Variabel } \\
\text { Dependen }\end{array}$ & Harga Saham & $\begin{array}{l}\text { Rata-rata harga saham } \\
\text { penutupan tiga bulan } \\
\text { setelah akhir tahun buku }\end{array}$ \\
\hline
\end{tabular}

Penentuan sampel dalam penelitian ini menggunakan teknik purposive sampling, yaitu teknik penentuan sampel dengan pertimbangan tertentu (Sugiyono, 2012:122). Pertimbangan yang digunakan dalam melakukan pemilihan sampel tersebut adalah sebagai berikut:

1. Bank-bank tersebut terdaftar di Bursa Efek Indonesia dan tidak sedang dalam proses delisting untuk periode 2010-2013 secara bertutut-turut.
2. Bank-bank tersebut menerbitkan laporan keuangan tahunan untuk periode 2010-2013 secara berturut-turut.

3. Bank-bank tersebut mengungkapkan nilai pinjaman baik nilai tercatat maupun nilai wajar dalam catatan atas laporan keuangannya untuk periode 2010-2013 secara berturut-turut.

Berikut merupakan tabel yang disediakan peneliti untuk melihat jumlah sampel akhir yang memenuhi kriteria di atas (Tabel 2).

Tabel 2. Prosedur Seleksi Sampel

\begin{tabular}{clc}
\hline No & \multicolumn{1}{c}{ Klasifikasi } & Perusahaan \\
\hline 1 & $\begin{array}{l}\text { Bank yang terdaftar di BEI dan tidak } \\
\text { sedang dalam proses delisting periode }\end{array}$ & 116 \\
& 2010-2013. \\
2 & $\begin{array}{l}\text { Bank yang tidak mengungkapkan } \\
\text { nilai tercatat (book value) dan nilai } \\
\text { wajar (fair value) pinjaman selama } \\
\text { periode 2010-2013 secara berturut- } \\
\text { turut. }\end{array}$ \\
\hline & Jumlah keseluruhan sampel \\
\hline
\end{tabular}

\section{Teknik Analisis dan Pengujian Hipotesis}

Untuk melakukan perhitungan dan pengujian statistik, penelitian ini menggunakan program SPSS (Statistics Program for Social Science) versi 18.0 untuk Windows. Teknik analisis data dalam penelitian ini akan menggunakan regresi linier berganda dan uji hipotesis dilakukan secara bersama-sama (uji F) dan uji hipotesis secara parsial atau secara individu masing-masing variabel independen terhadap variabel dependennya (uji t). Sebelum dilakukan uji-uji tersebut, atas seluruh variabel penelitian dilakukan analisis statistik deskriptif untuk menggambarkan sampel yang diteliti yaitu dengan cara menentukan mean, median, standard deviation, minimum, dan maximum.

Adapun persamaan regresi linier berganda yang digunakan adalah:

Price $=\alpha+B_{1}$ DIFF_BLFL $+B_{2}$ BVE $+\beta_{3}$ EPS + ${ }_{34} \mathrm{SIZE}+\varepsilon$

dimana:

Price : Harga saham

A : Konstanta

$B_{1,2,3,4} \quad$ : Koefisien regresi yang menunjukkan angka peningkatan ataupun penurunan variabel dependen yang didasarkan pada variabel independen.

DIFF_BLFL: Selisih loans book value dan loans fair value

$\mathrm{BE} \quad$ : Book value per share

EPS : Earnings per share 


\section{SIZE : Ukuran perusahaan yang diproksi- kan dengan log total aset \\ E : Standar error}

Sebelum dianalisis lebih lanjut, model penelitian diuji asumsi klasik yaitu normalitas, heterokedastisitas, dan multikolinieritas. Kriteria pengambilan keputusan uji hipotesis yang digunakan penelitian ini adalah jika Bi dalam persamaan (1) tidak sama dengan nol (0) dan signifikansinya kurang dari 0,05 berarti variabel-variabel independen yang diteliti bisa digunakan untuk memprediksi variabel dependen (harga saham).

\section{Analisis Sensitivitas}

Analisis sensitivitas merupakan suatu analisis untuk dapat melihat pengaruh-pengaruh yang akan terjadi akibat keadaan yang berubahubah. Pengujian analisis sensitivitas dalam penelitian ini dilakukan pada sampel perusahaan yang antara loans book value dan loans fair value mempunyai perbedaan nilai. Dari keseluruhan sampel yang dipilih, terdapat 48 sampel yang menunjukkan selisih loans book value dan loans fair value yang tidak sama dengan nol. Analisis regresi pada sampel ini menggunakan persamaan regresi linier berganda yang sama seperti pada persamaan yang telah dijelaskan sebelumnya. Hal ini dilakukan untuk menguji sensitivitas sampel yang dipilih apakah akan beperngaruh terhadap hasil jika hanya mempertimbangkan perusahaan yang antara loans book value dan loans fair value mempunyai perbedaan nilai.

\section{HASIL PENELITIAN DAN PEMBAHASAN}

\section{Analisis Statistik Deskriptif}

Perusahaan yang digunakan sebagai sampel dalam penelitian ini berjumlah 27 perusahaan perbankan yang terdaftar di Bursa Efek Indonesia yang telah memenuhi kriteria pemilihan sampel. Periode pengamatan selama 2010-2013 membuat sampel yang digunakan berjumlah total 108 sampel. Berikut ini merupakan analisis statistik deskriptif masing-masing variabel penelitian.

Berdasarkan Tabel 2 di atas, maka dapat disimpulkan masing-masing variabel sebagai berikut:

1. Harga Saham (Price)

Rata-rata harga saham pada perusahaan sampel adalah sebesar 2.039,75 dengan standar deviasi sebesar 2.525,04. Harga saham paling kecil yaitu 83,94 dimiliki oleh Bank Capital Indonesia Tbk, sedangkan harga saham paling tinggi yaitu 10.174,17 dimiliki oleh Bank Central Asia Tbk.
2. Selisih Loans Book Value dan Loans Fair Value (DIFF_BLFL)

Rata-rata selisih loans book value dan loans fair value pada perusahaan sampel adalah sebesar -3,80E11 dengan standar deviasi sebesar 1,34E12. Selisih loans book value dan loans fair value paling kecil yaitu -7,24E12 dimiliki oleh Bank Tabungan Pensiunan Nasional Tbk, sedangkan selisih loans book value dan loans fair value paling tinggi yaitu 1,31E12 dimiliki oleh Bank Mandiri (Persero) Tbk.

3. Book Value Per Share (BVE)

Rata-rata book value per share pada perusahaan sampel adalah sebesar 972,70 dengan standar deviasi sebesar 934,05. Book value per share terkecil yaitu 66,75 dimiliki oleh Bank Pundi Indonesia Tbk, sedangkan book value per share terbesar yaitu 3.805,31 dimiliki oleh Bank Mandiri (Persero) Tbk.

4. Earnings Per Share (EPS)

Rata-rata earnings per share pada perusahaan sampel adalah sebesar 162,21 dengan standar deviasi sebesar 203,24. Earnings per share terkecil yaitu -25,96 dimiliki oleh Bank Pundi Indonesia Tbk, sedangkan earnings per share terbesar yaitu 865,21 dimiliki oleh Bank Rakyat Indonesia (Persero) Tbk.

5. Ukuran Perusahaan (SIZE)

Rata-rata ukuran perusahaan pada perusahaan sampel adalah sebesar 13,49 dengan standar deviasi sebesar 0,83. Ukuran perusahaan terkecil yaitu 10,00 yang dimiliki oleh Bank Nusantara Parahyangan Tbk, sedangkan Ukuran perusahaan terbesar yaitu 14,87 yang dimiliki oleh Bank Mandiri (Persero) Tbk.

Tabel 3. Statistik Deskriptif

\begin{tabular}{lrrrr}
\hline Variabel & \multicolumn{1}{c}{ Min } & \multicolumn{1}{c}{ Max } & Mean & $\begin{array}{c}\text { Std. } \\
\text { Deviation }\end{array}$ \\
\hline Price & 83,94 & $10.174,17$ & $2.039,75$ & $2.525,04$ \\
DIFF_BL & $-7,24 \mathrm{E} 12$ & $1,31 \mathrm{E} 12$ & - & $1,34 \mathrm{E} 12$ \\
FL & & & $3,80 \mathrm{E} 11$ & \\
BE & 66,75 & $3.805,31$ & 972,70 & 934,05 \\
EPS & $-25,96$ & 865,21 & 162,21 & 203,24 \\
SIZE & 10,00 & 14,87 & 13,49 & 0,83 \\
\hline
\end{tabular}

\section{Hasil Analisis Regresi Linier Berganda}

Hasil analisis asumsi klasik menunjukkan bahwa model penelitian tidak mengandung potensi masalah. Normal Probability Plot menunjukkan bahwa data menyebar di sekitar garis diagonal dan mengikuti arah garis diagonalnya. Hasil uji asumsi klasik juga menunjukkan bahwa nilai tolerance dari masing-masing variabel independen berada di antara nilai 0,0-1 dan VIF dari masingmasing variabel independen memiliki nilai yang 
lebih rendah dari angka 10, sehingga dapat disimpulkan bahwa data sampel bebas dari multikolinearitas. Gambar scatterplot untuk uji heterokedastisitas menunjukkan bahwa titik-titik tidak membentuk pola tertentu dan menyebar di atas dan di bawah angka 0 pada sumbu $\mathrm{X}$, sehingga disimpulkan bahwa data tidak mengalami heterokedastisitas.

Koefisien determinasi $\left(\mathrm{R}^{2}\right)$ pada Tabel 3 yang dihasilkan dari regresi linier berganda sebesar 0,839 dan adjusted $\mathrm{R}^{2}$ sebesar 0,833. Maka dari hasil tersebut dapat disimpulkan bahwa selisih loans book value dan loans book value, book value per share, earnings per share dan ukuran perusahaan memiliki kontribusi sebesar 83,3\% dalam mempengaruhi harga saham sedangkan 16,7\% sisanya dipengaruhi oleh variabel independen lain yang tidak diteliti.

Tabel 4. Hasil Analisis Regresi Linier Berganda

\begin{tabular}{lll}
\hline \multicolumn{1}{c}{ Model } & \multicolumn{1}{c}{$\beta$} & \multicolumn{1}{c}{$\operatorname{Sig} \beta$ (t-hitung) } \\
\hline Konstanta & $-3.790,243$ & \\
DIFF_BLFL & $8,673 \mathrm{E}-11$ & 0,251 \\
BE & $-0,268$ & 0,357 \\
EPS & 11,706 & $0,000^{* *}$ \\
SIZE & 312,994 & $0,050^{* *}$ \\
\hline$R^{2}$ & 0,839 \\
Adjusted R & & 0,833 \\
Sig $\beta$ (F-hitung) & 0,000 \\
\hline \multicolumn{2}{c}{ Variabel Dependen: Price } \\
\hline
\end{tabular}

** Signifikan pada level 5\%

Regresi linier berganda pada penelitian ini menghasilkan nilai signifikansi uji $\mathrm{F}$ sebesar 0,000 yang lebih kecil dari 0,05. Dengan demikian maka dapat disimpulkan bahwa terdapat pengaruh yang signifikan dari selisih loans book value dan loans fair value, book value per share, earnings per share dan ukuran perusahaan terhadap harga saham.

Sedangkan secara parsial, untuk selisih loans book value dan loans fair value menghasilkan nilai koefisien yang bertanda positif dengan tingkat signifikansi sebesar 0,251 yang lebih besar dari 0,05 , berarti bahwa terdapat pengaruh positif namun tidak signifikan dari loans book value dan loans fair value terhadap harga saham. Book value per share menghasilkan nilai koefisien yang bertanda negatif dengan tingkat signifikansi sebesar 0,357 yang lebih besar dari 0,05, berarti bahwa terdapat pengaruh negatif namun tidak signifikan dari book value per share terhadap harga saham. untuk variabel earnings per share menghasilkan nilai koefisien yang bertanda positif dengan tingkat signifikansi sebesar 0,000 yang lebih kecil dari 0,05, berarti bahwa terdapat pengaruh positif dan signifikan dari earning per share terhadap harga saham. Ukuran perusahaan menghasilkan nilai koefisien yang bertanda positif dengan tingkat signifikansi sebesar 0,050 yang lebih kecil sama dengan 0,05, berarti bahwa terdapat pengaruh positif dan signifikan dari ukuran perusahaan terhadap harga saham.

\section{Hasil Analisis Sensitivitas}

Analisis sensitivitas pada penelitian dilakukan pada sampel perusahaan yang antara loans book value dan loans fair value mempunyai perbedaan nilai. Dari keseluruhan sampel yang dipilih, terdapat 48 sampel yang menunjukkan selisih loans book value dan loans fair value. Hasil analisis regresi linier berganda pada sampel ini akan dijelaskan pada Tabel 5 .

Tabel 5. Hasil Analisis Regresi Linier Berganda 48 Sampel

\begin{tabular}{lcl}
\hline \multicolumn{1}{c}{ Model } & \multicolumn{1}{c}{$\beta$} & $\operatorname{Sig} \beta$ (t-hitung) \\
\hline Konstanta & $-8.864,072$ & \\
DIFF_BLFL & $2,500 \mathrm{E}-10$ & $0,018^{* *}$ \\
$\mathrm{BE}$ & $-1,462$ & $0,009^{* *}$ \\
$\mathrm{EPS}$ & 17,074 & $0,000^{* *}$ \\
$\mathrm{SIZE}$ & 748,370 & $0,057^{*}$ \\
$\mathrm{R}^{2}$ & & 0,826 \\
Adjusted R & 0,810 \\
Sig $\beta$ (F-hitung) & 0,000 \\
\hline \multicolumn{2}{c}{ Variabel Dependen: Price } \\
\hline
\end{tabular}

**Signifikan pada level 5\%

*Signifikan pada level 10\%

Koefisien determinasi $\left(\mathrm{R}^{2}\right)$ pada Tabel 4 yang dihasilkan dari regresi linier berganda sebesar 0,826 dan adjusted $\mathrm{R}^{2}$ sebesar 0,810. Maka dari hasil tersebut dapat disimpulkan bahwa selisih loans book value dan loans book value, book value per share, earnings per share dan ukuran perusahaan memiliki kontribusi sebesar $81 \%$ dalam mempengaruhi harga saham sedangkan 19\% sisanya dipengaruhi oleh variabel independen lain yang tidak diteliti.

Regresi linier berganda pada penelitian ini menghasilkan nilai signifikansi uji $\mathrm{F}$ sebesar 0,000 yang lebih kecil dari 0,05. Dengan demikian maka dapat disimpulkan bahwa terdapat pengaruh yang signifikan dari selisih loans book value dan loans fair value, book value per share, earnings per share dan ukuran perusahaan terhadap harga saham.

Sedangkan secara parsial, untuk selisih loans book value dan loans fair value menghasilkan nilai koefisien yang bertanda positif dengan tingkat signifikansi sebesar 0,018 yang lebih kecil dari 0,05 , berarti bahwa terdapat pengaruh positif dan signifikan dari loans book value dan loans fair value terhadap harga saham. Book value per share menghasilkan nilai koefisien yang bertanda 
negatif dengan tingkat signifikansi sebesar 0,009 yang lebih kecil dari 0,05 , berarti bahwa terdapat pengaruh negatif dan signifikan dari book value per share terhadap harga saham. untuk variabel earnings per share menghasilkan nilai koefisien yang bertanda positif dengan tingkat signifikansi sebesar 0,000 yang lebih kecil dari 0,05, berarti bahwa terdapat pengaruh positif dan signifikan dari earning per share terhadap harga saham. Ukuran perusahaan menghasilkan nilai koefisien yang bertanda positif dengan tingkat signifikansi sebesar 0,057 yang lebih besar dari 0,05 namun lebih kecil dari 0,010, berarti bahwa terdapat pengaruh positif dan signifikan pada level 10\% dari ukuran perusahaan terhadap harga saham.

Dari hasil tersebut, maka dapat disimpulkan bahwa hasil regresi pada penelitian ini sensitive terhadap sampel yang digunakan. Jika regresi dilakukan hanya pada sampel perusahaan dimana antara loans book value dan loans fair value mempunyai perbedaan nilai, hasil regresi ini menunjukkan bahwa selisih loans book value dan loans fair value, book value per share, earnings per share dan ukuran perusahaan lebih berpengaruh signifikan terhadap harga saham dibandingkan dengan sampel secara keseluruhan. Sehingga dapat disimpulkan bahwa sampel ini lebih sensitive untuk diuji pengaruh dan value relevance- nya terhadap harga saham.

\section{Pengaruh Selisih Loans book value dan Loans Fair Value terhadap Harga Saham}

Berdasarkan pada Tabel 4 dan Tabel 5, hasil analisis regresi linier berganda menunjukkan bahwa nilai $B$ untuk variabel selisih loans book value dan loans fair value (DIFF_BLFL) adalah bertanda positif dengan nilai signifikansi $B$ sebesar 0,018 lebih kecil dari tingkat signifikan 0,05 maka secara parsial terdapat pengaruh yang signifikan dari selisih loans book value dan loans fair value terhadap harga saham. Hal ini berarti bahwa pengungkapan loans fair value mempunyai value relevance dalam menjelaskan harga saham. Hasil ini sesuai dengan penelitian Drago, et al. (2013).

Menurut Drago, et al. (2013) pengaruh yang signifikan ini disebabkan perbankan menerapkan IAS 39 tentang pengakuan dan pengukuran instrumen keuangan termasuk loans. Hal serupa dilakukan oleh perbankan yang menjadi sampel penelitian ini, perbankan mulai patuh dalam mengungkapkan fair value instrumen keuangan nya terkait dengan pemberlakuan penerapan PSAK 55, dimana pengakuan dan pengukuran instrumen keuangan khususnya loans yang menjadi variabel penelitian ini diukur dengan menggunakan biaya perolehan diamortisasi dan metode suku bunga efektif, serta bank mempunyai kewajiban dalam mengungkapkan fair value-nya menunjukkan bahwa pemberlakuan lebih banyak PSAK berbasis IFRS, oleh investor dinilai sebagai peningkatan kualitas laporan keuangan (Suprihatin dan Tresnaningsih, 2013). Sehingga dapat disimpulkan bahwa selisih loans book value dan loans fair value mempunyai value relevance dalam menjelaskan harga saham.

\section{Pengaruh Book Value Per Share terhadap Harga Saham}

Berdasarkan pada Tabel 4 dan Tabel 5, hasil analisis regresi linier berganda menunjukkan bahwa nilai $B$ untuk variabel book value per share (BVE) adalah bertanda negatif dengan nilai signifikansi 6 sebesar 0,009 lebih kecil dari tingkat signifikan 0,05 maka secara parsial terdapat pengaruh yang signifikan dari book value per share terhadap harga saham. Hal ini sesuai dengan penelitian Drago, et al. (2013). Tetapi penelitian ini tidak mendukung penelitian yang dilakukan oleh Agostino, et al. (2012).

Book value per share menunjukkan aktiva bersih yang dimiliki oleh pemegang saham dengan memiliki satu lembar saham, dimana aktiva bersih adalah sama dengan total ekuitas pemegang saham (Jogiyanto, 2007). Jumlah saham beredar yang tinggi namun tidak diimbangi dengan kenaikan jumlah ekuitas atau aktiva bersih akan menyebabkan kinerja pasar atau peluang pasar rendah dan berdampak pada rendahnya harga saham serta sebaliknya. Menurut pendapat Collins, et al. (1999) bahwa "this variable is more important when current earnings do not provide a good proxy for future earnings". Hal ini menunjukkan bahwa book value per share akan menjadi penting ketika earnings tidak menggambarkan pengukuran yang baik untuk laba masa depan, sehingga jika earnings sudah mencerminkan laba masa depan, investor hanya akan melihat earnings dan book value per share dianggap tidak penting lagi.

\section{Pengaruh Earnings Per Share terhadap Harga Saham}

Berdasarkan pada Tabel 4 dan Tabel 5, hasil analisis regresi linier berganda menunjukkan bahwa $B$ untuk variabel earnings per share (EPS) adalah bertanda positif dengan nilai signifikansi $B$ sebesar 0,000 lebih kecil dari tingkat signifikan 0,05 maka secara parsial ada pengaruh yang signifikan dari earnings per share terhadap harga saham. Hal ini sesuai dengan penelitian Agostino, et al. (2012) dan Drago, et al. (2013). 
Pengaruh yang signifikan ini disebabkan oleh investor lebih merespon berapa laba bersih yang dapat dihasilkan perusahaan dalam setiap lembar saham yang diinvestasikan. Jika earnings per share meningkat, maka harga saham juga akan meningkat. Hal ini mencerminkan bahwa potensi perusahaan dalam menghasilkan laba adalah cerminan bagaimana perusahaan mengelola investasi dana dari investor dengan baik. Maka dapat disimpulkan bahwa earnings per share mempunyai value relevance dalam menjelaskan harga saham.

\section{Pengaruh Ukuran Perusahaan terhadap Harga Saham}

Pengaruh yang signifikan dalam penelitian ini menunjukkan bahwa. bahwa perusahaan yang berukuran besar cenderung dapat melakukan diversifikasi dan dapat menghasilkan laba yang lebih yang relatif tinggi karena mudah melakukan akses ke pasar untuk mendapatkan modal dibandingkan dengan perusahaan yang berukuran kecil. Hal ini menunjukkan bahwa ketika perusahaan besar dapat menghasilkan laba yang tinggi, investor akan tertarik untuk membeli saham perusahaan yang berukuran besar dibandingkan dengan perusahaan yang lebih kecil, sehingga harga saham akan naik (Djadmiko, 2008). Maka dapat disimpulkan bahwa ukuran perusahaan berpengaruh signifikan positif dan mempunyai value relevance dalam menjelaskan harga saham.

\section{KESIMPULAN DAN SARAN}

\section{Kesimpulan}

Hasil penelitian ini menunjukkan bahwa selisih loans book value dan loans fair value berpengaruh dan mempunyai value relevance dalam menjelaskan harga saham ketika loans book value dan berbeda dengan loans fair value-nya. Hal ini menandakan bahwa pengungkapan loans fair value yang merupakan syarat wajib bagi perbankan akan direspon oleh investor ketika loans book value dan loans fair value-nya mempunyai perbedaan nilai, sehingga dapat disimpulkan bahwa selisih loans book value dan loans fair value mempunyai value relevance dalam menjelaskan harga saham.

Book value per share berpengaruh dan mempunyai value relevance dalam menjelaskan harga saham ketika earnings tidak menggambarkan laba masa depan. Hal ini menandakan bahwa informasi book value per share akan direspon investor ketika earnings tidak menggambarkan pengukuran yang baik untuk laba masa depan.
Earnings per share berpengaruh dan mempunyai value relevance dalam menjelaskan harga saham. Hal ini menandakan bahwa informasi earnings per share yang merupakan indikator utama dalam menentukan harga saham mendapat respon baik dari investor, sehingga earning per share mempunyai value relevance dalam menjelaskan harga saham.

Ukuran perusahaan berpengaruh dan mempunyai value relevance dalam menjelaskan harga saham. Hal ini menandakan bahwa baik ukuran perusahaan besar maupun kecil mendapat respon baik dari investor, sehingga ukuran perusahaan mempunyai value relevance dalam menjelaskan harga saham.

\section{Saran}

Pada penelitian selanjutnya diharapkan dapat menggunakan variabel instrumen keuangan jenis avalaible for sale, held to maturity securities, dimana nilai wajar nya tersedia di pasar aktif. Sehingga lebih mencerminkan nilai wajar dengan penilaian yang objektif.

Pengungkapan loans book value dan loans fair value dalam catatan atas laporan keuangan perusahaan merupakan syarat wajib bagi perusahaan. Namun, terdapat beberapa perusahaan yang tidak mengungkapkan fair value dari loans pada periode awal penerapan PSAK 55. Untuk penelitian selanjutnya diharapkan dapat memilih periode dimana perusahaan benar-benar mengungkapkan loans book value dan loans fair value.

\section{DAFTAR PUSTAKA}

Agostino, M., Drago, D., and Silipo, D. (2012). The Value Relevance of IFRS in the European Banking Industry. Review of Quantitative Finance and Accounting, 36(3), 437-457.

Collins, D. W., Pincus, M., and Xie, H. (1999). Equity valuation and negative earnings: The role of book value of equity. The Accounting Review, 74(1), 29.

Dendawijaya, L. (2005). Manajemen Perbankan. Jakarta: Penerbit Ghalia Indonesia.

Djadmiko, D. (2008). Relevansi Nilai Laba, Nilai Buku dan Ukuran Perusahaan Terhadap Kinerja Saham: Hubungan Nonlinier. Tesis. Surakarta: Program Studi Magister Akuntansi, Universitas Sebelas Maret.

Drago, D., Mazzuca, M., and Colonel, R. T. (2013). Do Loans Fair Value Affect Market Value? Evidence From European Banks. Journal of Financial Regulation and Compliance, 21(2), 108-120.

Francis, J., and Schipper, K. (1999). Have Financial Statements Lost Their Relevance?. Journal of Accounting Research, 37(1), 319-352. 
Ghozali, I. (2005). Aplikasi Analisis Multivariate dengan Program SPSS. Semarang: Badan Penerbit Universitas Diponegoro.

Hassan, M. S. and Norman, M. S. (2010). The Value Relevance of Financial Instruments Disclosure in Malaysian Firms Listed in the Main Board of Bursa Malaysia. International Journal of Economics and Management, 4(2), 243-270.

IAI. 2012. Standar Akuntansi Keuangan - PSAK 55 (Revisi 2011) Instrumen Keuangan: Pengakuan dan Pengukuran. Jakarta: Ikatan Akuntan Indonesia.

Jogiyanto, H. (2007). Teori Portofolio dan Analisis Investasi. Edisi Kelima. Yogyakarta: BPFEYogyakarta.

Khurana, I. K. and Kim, M. . (2003). Relative Value Relevance of Historical Cost vs. Fair Value: Evidence from Bank Holding Companies. Journal of Accounting and Public Policy, 22, 19-42.
Morris, C. S. and Sellon, G. H. Jr. (1991). Market Value Accounting for Banks: Pros and Cons. Economic Review. Page 5-19.

Nissim, D. (2003). Reliability of Banks's Fair Value Disclosure for Loans. Review of Quantitative Finance and Accounting, 20, 335-384.

Reinita, I. S. M. (2011). Value Relevance of R \& D Reporting. Master Thesis. University of Maastricht Faculty of Economics and Business Administration.

Sonbay, Y. Y. (2010). Perbandingan Biaya Historis dan Nilai Wajar. Kajian Akuntansi, 2(1), 1-8.

Sugiyono. (2012). Statistika Untuk Penelitian. Bandung: CV. Alfabeta.

Suprihatin, S. and Elok, T. (2013). Pengaruh Konvergensi International Financial Reporting Standards terhadap Relevansi Nilai Informasi Akuntansi: Studi Empiris pada Perusahaan yang Terdaftar di BEI. Simposium Nasional Akuntansi 16. Manado. 